Artikel Konseptual

\title{
PENDIDIKAN SEJARAH DAN KARAKTER BANGSA: SEBUAH PENGANTAR DIALOG
}

Hariyono

hariyonosejunm@yahoo.com

Wakil Ketua Badan Pembinaan Ideologi Pancasila.

\begin{abstract}
Learning history is important to strenghten character education. Through learning history the existence of ideal character need to reinterprate in state and nation life, so it can be suited to the needs. Therefore, it is important to develop new point of view from educators, so they can be teach and embed the values in accordance with the time. The educators have to positioning their own as a inspirator, motivator, and role model in learning history. So that those educators will be able to invite the students to learn from cross time and area. Example can be taken from the simplicity and the willingness of generations before us and or life that is practiced in other countries. This is intended so that the establishment-creation of national character is not exclusive.
\end{abstract}

Key words: learning history, character of nation, reinterpretation

\section{PENDAHULUAN}

Salah satu tantangan yang dihadapi bangsa Indonesia sejak awal kemerdekaan hingga kini adalah pendidikan karakter. Kemunduran karakter masyarakat Nusantara yang sebelumnya menjadi masyarakat merdeka, suka menjelajah dan menghasilkan pelbagai karya menjadi redup setelah lama hidup dalam suasanan penjajahan. Kerugian terbesar masyarakat Indonesia selama masa penjajahan bukan pada hilangnya aset ekonomi yang dieksploitasi maupun terbunuhnya banyak pemimpin perlawanan. Kerugian terbesar disebabkan oleh hilangnya karakter manusia merdeka dan tidak memiliki kepercayaan diri yang kemudian sering disebut "bermental Inlander".

Usaha menemukan kembali karakter masyarakat Nusantara justru sering terhambat oleh kepercayaan diri yang membatasi (self limited belief) yang tanpa sadar dipelihara, misalnya "watuk ada obatnya tetapi watak tidak ada obatnya". Dalam kondisi yang semacam ini, meminjam istilah Fromm, (1995: 15) kita berhadapan dengan "cacat yang sudah terpolakan secara sosial". Konsekuensinya sisi negatif karakter manusia sebagaimana pernah diungkap oleh Mochtar Lubis, (1981) dan Koentjaraningrat (1987) 
seolah menjadi sesuatu yang given dan tidak dapat diubah karena tidak dilihat dari perspektif sejarah. Karakter itu bukan sekedar warisan biologis, melainkan lebih merupakan hasil pembiasaan (habituasi) sekaligus konstruksi sosial, bukan sesuatu yang given.

Sayangnya sektor pendidikan (termasuk pendidikan sejarah) hingga kini belum dapat membentuk karakter subyek didiknya sesuai dengan tantangan zamannya. Moralitas bangsa yang dibangun para nenek moyang dan dirumuskan kembali oleh para pendiri bangsa berupa pandangan hidup Pancasila masih belum dapat diaktualisasikan secara maksimal. Nilai-nilai Pancasila sebagai landasan moral kehidupan berbangsa dan bernegara masih perlu digali dan diaktualisasikan dalam pembelajaran sejarah secara kontinyu dan mendalam.

Proses pendirian bangsa dan Negara Indonesia yang menempatkan Pancasila sebagai dasar Negara belum dipahami secara luas dan mendalam oleh kalangan terpelajar. Bahan ajar sejarah belum menjadi bacaan yang menarik serta merangsang rasa ingin tahu pembacanya. Penyajiannya sering kurang menampilkan nilai-nilai kesejarahan yang tidak hanya membahas masa lampau sebagai suatu peristiwa melainkan juga suatu proses yang memberikan suatu visi ke depan bagaimana bangsa Indonesia sebagai suatu bangsa dapat menyongsong dan menghadapi tantangan kehidupan yang lebih baik. Visi bangsa yang merdeka, maju, berdaulat, adil dan makmur jarang disinggung dalam proses pembelajaran sejarah (Poespowardojo, 1989: 239). Padahal sebagaimana yang dinyatakan oleh almarhum Soedjatmoko (1986: 64) bahwa "suatu bangsa yang sedang membangun, suatu bangsa yang sedang berjuang, tidak bisa lain daripada melangkahkan kakinya pada jalan yang disinari oleh cita-citanya, dengan penuh kesadaran tentang yang sudah, yaitu sejarahnya".

Kenyataan tersebut membuktikan bahwa keberadaan bangsa Indonesia sebagai suatu "proses yang menjadi" selalu dalam pelbagai goncangan dan tantangan. Upaya untuk menjaga kepribadian bangsa sekaligus mengembangkan "daya cipta" menjadi sesuatu yang bersifat strategis dan mendasar.

Ada kesan masyarakat Indonesia cenderung gagap melihat perubahan, termasuk perubahan sejarah. Sejak zaman penjajahan, pergerakan nasional, revolusi nasional, demokrasi liberal, demokrasi terpimpin, Orde Baru, dan orde reformasi pembelajaran dan pendidikan karakter cenderung dianggap sebagai penggalan sejarah yang saling terpisah antara periode yang satu dengan yang lain. Dimensi perubahan dalam kelanjutan (change in continuity) seolah hilang. Konsekuensinya sejarah yang notabene merupakan perubahan cenderung dipahami dalam penggalan-penggalan (atom narrative), bukan kisah yang berangkai dalam keberlanjutan (strings narrative). Konsekuensinya pendidikan sejarah tidak mampu menjadi bahan refleksi, referensi dan orientasi kehidupan akibat kehilangan perspektif kesejarahannya. Padahal 63 tahun yang lalu dalam 
Seminar Sejarah di Yogyakarta, Soedjatmoko telah menyatakan bahwa kisah sejarah tidak ada yang lengkap dan jadi.

“... gambar-gambar sejarah dijalin oleh penyelidikan ilmu sejarah, bukanlah gambargambar yang pasti dan tetap. Gambar-gambar itu senantiasa berubah sesuai dengan pendapat baru di dalam penyelidikan yang berjalan terus itu, dan juga, sebagai akibat daripada perubahan di dalam pertanyaan-pertanyaan yang dimajukan kepada sejarah, sesuai dengan keperluan menurut perubahan keadaan sejarah. Hal ini memang sudah menjadi sifat penyelidikan ilmu sejarah. Ilmu sejarah tidak dapat memberi kepastian-kepastian yang tetap. Barangsiapa mencari kepastian-kepastian semacam itu, janganlah ia bertanya kepada ilmu sejarah." (Soedjatmoko, 1984; 32-33)

Dalam suasana kegalauan tersebut masyarakat telah mengalami dislokasi dan disorientasi. Krisis identitas terjadi akibat masyarakat gagal membangun dan menegaskan diri sebagai entitas komunal-spiritual yang khas dan bhineka dalam lanskap kehidupan yang kini serba digital. Masyarakat juga mengalami krisis orientasi akibat gagal merekonstruksi arah dan tujuan ke masa depan. Mereka sulit memosisikan diri secara bijak dalam proses perubahan budaya yang semakin mondial atau global. Identitas diri baik sebagai pribadi maupun komunitas kolektif mudah mengalami kekacauan. Nalar dan nurani sebagai karakteristik manusia yang berbasis nilai luhur sebagaimana diformulasikan dalam pandangan hidup sekaligus ideology negara, Pancasila, sering mengalami distorsi, karena tidak menyatunya Geest, Wil dan Daad. Karakter bangsa Indonesia telah mengalami diskrapensi antara apa yang dibicarakan dengan apa yang dilakukan.

Nilai-nilai luhur yang dibingkai dalam Pancasila banyak yang belum terealisasi dalam kehidupan sehari-hari. Pencasila sebagai "titik temu" yang memungkinkan persatuan pelbagai elemen bangsa menerima dan menjadikan sebagai "titik tumpu" yang oleh bung Karno disebut sebagai "meja statis" perlu diikuti dengan posisi Pancasila sebagai "titik tuju", yaitu "Leitstar dinamis yang dapat memberikan "harapan", rasa mampu, Krachtgevoel, dan kemampuan yang sebenarnya, de werkelijke kracht (Soekarno, 2017, 127) bagi (maha)siswa berada dalam suasana "pendidikan yang berpengharapan dan berkemampuan". Dalam suasana yang demikian subyek didik distimulasi untuk menjadi sosok pribadi yang berani berpikir besar dan berjiwa besar. Untuk itulah penguatan pendidikan karakter dalam pembelajaran sejarah memiliki peran yang cukup signifikan. Kita diajak untuk melakukan refleksi terhadap pendidikan sejarah dan pembentukan karakter. Keberadaan karakter ideal perlu di “reinterpretasi” dalam kehidupan berbangsa dan bernegara agar sesuai dengan kebutuhan zaman. Proses pergaulan dunia yang makin intensif dengan perkembangan teknologi informasi, komunikasi dan transportasi yang begitu cepat membuat kebudayaan kontemporer bersifat "tunggang langgang". 
Hal ini perlu mendapat penekanan karena realitas dan sikap generasi muda zaman

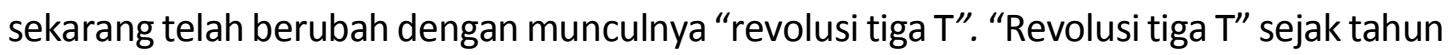
1980 -an sering digunakan untuk menjelaskan terjadinya perubahan yang mendasar tentang perekonomian dan dunia usaha yang juga berpengaruh terhadap hubungan social sebagai konsekuensi dari perkembangan teknologi di bidang telekomunikasi, transportasi dan turisme. Informasi yang tersedia dalam dunia digital dan dapat diakses kapan saja dan dimana saja seolah dapat memampatkan ruang dan waktu sehingga sangat berpengaruh terhadap kepribadian generasi muda (generasi now). Nilai-nilai lama seolah terasa tidak relevan sementara nilai-nilai baru belum terformulasi dan terinternalisasi.

Dalam konteks yang demikian banyak pihak prihatin dengan karakter bangsa dalam menghadapi tantangan dunia yang telah berubah secara mendasar. Penulis beranggapan bahwa pendidikan karakter merupakan sesuatu yang inheren dalam dirinya. Setiap pendidikan pada hakekatnya merupakan pengenalan, penanaman dan pengembangan karakter melalui internalisasi dan habituasi nilai (Ryan \& Bohlin, 1999). Hanya melalui pendidikan karakter yang bersumber dari pola pikir (mindset) moralitas bangsa dapat dijaga dan dikembangkan sesuai dengan kebutuhan dan tantangan zaman. Situasi ini dapat diawali dari bagaimana pendidik memandang posisi dan profesinya.

\section{CARA PANDANG PENDIDIK}

Pendidik seyogyanya memahami bahwa seseorang tidak menyukai pelajaran atau matakuliah diawali dari ketidaksenangannya terhadap guru atau dosennya. Kondisi ini mengindikasikan bahwa proses pendidikan tidak semata-mata menciptakan relasi si pebelajar dengan materi yang dipelajari, tetapi juga diwarnai oleh "perjumpaan" pribadi si pebelajar dengan sang pendidik. Untuk itulah dalam proses pembelajaran sosok pendidik perlu mendapat perhatian yang signifikan selain membicarakan materi ajar serta metodologi pembelajarannya.

Penampilan pendidik dalam proses belajar biasanya menjadi pintu awal si pebelajar mengenal pelajaran yang dipelajari. Pendidik yang supel dan mampu menciptakan resonansi emosional dan intelektual dapat menjadi daya tarik siswa mengembangkan rasa ingin tahunya, terutama dalam bidang studi yang digeluti. Mereka yang suka sejarah biasanya diawali oleh rasa senang terhadap guru sejarah dan sebaliknya.

Pendidik dengan segala keunikannya biasanya menjadi awal bagi pembelajaran, termasuk belajar sejarah, yang tidak bisa seragam. Identitas dan integritas pendidik menjadi kunci awal dan utama proses pembelajaran (Palmer, 2009: 19). Identitas dalam hal 
ini adalah jaringan seputar pendidik sehingga semua kekuatan yang membangun kehidupan tersebut membentuk jatidirinya. Sementara itu, integritas dalam hal ini adalah segala sesuatu yang ada dalam jaringan kehidupan yang menjadi arah dalam membentuk dan atau membentuk ulang pola kehidupan pendidik.

Pendidik dengan rendah hati seyogyanya bersedia menciptakan relasi emosional dan intelektual guna melayani siswa atau mahasiswa. Untuk menjadi kunci perubahan, seyogyanya pendidik bersikap rendah hati, tidak menganggap dirinya selalu besar di hadapan para mahasiswanya. Tidak ada kunci yang lebih besar dari gemboknya. Pendidik dapat menyadari adaya relasi subyek/obyek yang ada pada masing-masing pendidik dan atau subyek didiknya. Hal ini karena tujuan pendidikan yang utama adalah memfasilitasi tumbuhkembangnya subyek didik menjalani hidup di masa kini dan masa akan datang.

Berangkat dari asumsi di atas, pendidikan karakter dalam pembelajaran sejarah tidak hanya fokus pada kisah sejarah sebagai materi pembelajaran yang beragam dan metodologi pembelajarannya yang memungkinkan memanfaatkan aneka sumber belajar, sarana belajar, metode belajar hingga evaluasi belajar yang tidak tunggal tetapi juga bagaimana menempatkan pendidik sebagai teladan, role model yang dapat melayani, memfasilitasi dan menuntun proses belajar (maha)siswanya. Secara umum siswa dan atau mahasiswa akan mencari teladan dalam membangun kebiasaan yang menjadi karakternya. Pendidik diharapkan dapat menjadi fasilitator, motivator dan inspirator dalam proses pembelajaran.

Sementara materi sejarah dalam era digital sudah sangat banyak dan mudah diakses. Big Data, yang banyak menyimpan informasi baik informasi akurat hingga hoax, memerlukan sikap kritis untuk memilah dan memilih informasi agar (maha)siswa tidak mabuk data.

Pendidik sejarah, perlu diajak untuk memandang cara pandang yang selama ini dilakukan agar lebih "sadar posisi" sekaligus dapat mengelola potensi yang ada dalam dirinya. Hal ini perlu ditekankan karena masih banyak pendidik yang enggan mempertanyakan anggapan atau asumsi yang mendasari cara pandang tentang diri, keluarga, profesi, sejarah dan kehidupan yang dialami. Seolah kehidupan sudah berjalan dengan sendirinya tanpa harus dipertanyakan. Konsekuensinya kita sebagai manusia menjalani kehidupan "prehistoris" tanpa menyadarinya. Wibowo (2013:149) meminjam istilah prehistoris dari filsuf Cekoslovakia, Jan Patocka, yang menyebutkan sebagai berikut.

"Diri manusia adalah sebuah ruang terbuka. Manusia bertautan dengan dua sisi dunia di mana ia hendak menemukan dirinya; di satu sisi, dunia prahistoris (atau ante-historis) dan di sisi lain dunia historis. Dunia prahistoris merujuk pada dunia yang dihayati sehari-hari tanpa banyak bertanya tentang makna dunia. Makna sehari-hari diterima begitu saja. Dunia diterima apa adanya tanpa curiga adanya 
problem di dalamnya. Sedangkan dunia historis adalah ketika orang mulai menemukan adanya problem terhadap makna tersebut. Dunia historis ditandai dengan adanya "problem". Sebuah penemuan problem yang tentu saja bisa ia iyai namun bisa juga ia tolak (dan kembali ke dunia prahistoris). Manusia adalah kesatuan dari dua dunia tersebut; perawatan jiwa berada dalam tegangan di antaranya."

Media dan berbagai bentuk iklan telah lama memprogram pikiran dan gagasan-gagasan kita secara bawah sadar secara terus menerus diterima tanpa dipertanyakan. Konsekuensi yang sering tidak disadari menyebabkan laku hidup mudah terperangkap dalam kesadaran palsu. Kondisi ini membuktikan bahwa belajar sejarah tidak dapat berlangsung secara alamiah. Walaupun manusia tidak ada yang dapat melarikan diri dari sejarah, namun idak dengan sendirinya manusia dapat belajar sejarah. Pendidikan sejarah adalah aktivitas kultural yang disadari atau tidak secara epistemologis selalu berbasis pada metodologi tertentu.

Sejarah membuktikan bahwa perubahan kualitatif kehidupan manusia, termasuk dunia ilmu pengetahuan dan teknologi dilandasi oleh perubahan cara pandang dan kadang pembalikan cara pandang (conversio). Misal dari pandangan Ptelomeus ke pandangan Copernicus, dari pandangan magis-religius ke pandangan rasional-empiris, dari sejarah keselamatan (providensia) bergeser pada sejarah yang empiris, dari theokrasi ke demokrasi dari behaviorisme ke konstruktivisme, dari teacher centered learning ke student centered learning dan sebagainya.

Ironisnya sudut pandang pendidik dalam pembelajaran sejarah sering tidak disadari atau bahkan jarang direfleksikan. Padahal sudut pandang yang tidak disadari atau tidak dinyatakan secara eksplisit cenderung menyembunyikan asumsi nilai yang kurang positif,

"karena dengan mendiamkan dan menyembunyikan asumsi nilai yang dianut, sambil dalam pada itu mengklaim adanya sikap bebas nilai, maka yang sesungguhnya terjadi adalah monopoli suatu nilai dan penilaian tertentu yang kemudian diberlakukan secara luas karena dianggap bukan lagi suatu nilai atau penilaian" (Kleden, 1987: xxxvi).

Konsekuensi dari hal tersebut menyebabkan pendidikan menjadi sarana dominasi, segregasi dan hegemoni yang tidak disadari oleh pendidik (Kreisberg, 1992).

Epistemologi sejarah dan pembelajarannya dipengaruhi oleh pelbagai perspektif yang beragam. Namun, bagi publik dan mungkin juga sebagian pendidik dimensi sudut pandang yang beragam belum dapat dipahami secara baik. Perbedaan dalam narasi sejarah sering dianggap sebagai sesuatu yang membingungkan. Mereka terbiasa dan beranggapan bahwa kebenaran sejarah itu bersifat tunggal. Minimnya kajian epistemologi sejarah dan atau pembelajarannya menyebabkan mereka umumnya kurang mampu memberikan gambaran yang cukup tentang pelbagai perspektif dalam penulisan 
dan pembelajaran sejarah. Keragaman paradigma dalam pembelajaran dan penulisan sejarah sering dianggap membingungkan. Mereka tidak menyadari bahwa kebingungan tersebut disebabkan oleh cara pandangnya yang monolit, penganut kebenaran tunggal (positivisme). Seolah ilmu itu netral dan bebas nilai. Padahal banyak teori pendidikan klasik yang dikembangkan dan dipengaruhi oleh akar sejarah dan ideologi yang dianut pengembangnya (Bigge, 1993).

Dalam batas tertentu pandangan positivisme relevan untuk memahami peristiwa sejarah yang global dan besar, namun kurang dapat menjelaskan detail peristiwa yang bersifat ideografis. Prinsip nomotetik dan asumsinya terhadap posisi ilmu sejarah yang bebas nilai dalam beberapa aspek memang dapat menjelaskan kecenderungan sejarah secara umum. Tetapi adanya keterkaitan suatu peristiwa sejarah dengan ruang dan waktu serta nilai-nilai budaya yang menyertainya menyebabkan keunikan dari suatu peristiwa sulit dipahami secara utuh, sehingga dimensi ideografis menjadi lebih relevan. Kondisi ini tidak harus menempatkan konsep nomotetik dan ideografis sebagai oposisi biner yang saling berlawanan. Keduanya adalah suatu dualitas yang berbeda tetapi tidak dapat dipisahkan, layaknya lingkaran hermeneutik bahwa yang umum dan yang khusus saling membutuhkan dan menjelaskan.

Untuk itu pembelajaran sejarah yang kontekstual menjadi sangat relevan (Johnson, 2007). Makna referensial, yaitu hubungan teks dengan dunia luar maupun makna tekstual, hubungan di dalam teks itu sendiri perlu dipahami oleh pendidik, karena subyek didik yang memiliki pengalaman dan pengetahuan yang beragam akan memaknai topic pembelajaran secara beragam. Pendidikan tidak dapat dipisahkan dari kehidupan sehingga pembelajaran yang bermakna selalu berbasis kehidupan termasuk kepentingan bangsa. Menurut Ki Hajar Dewantara (2013), pengajaran nasional itulah pengajaran yang selaras dengan penghidupan bangsa (maatschappelijk) dan kehidupan bangsa (culturureel). Belajar membaca dan menulis bukan sekedar untuk "liturgy", symbol inisiasi agar memperoleh gelar, melainkan suatu proses untuk meningkatkan kapasitas belajar (learning capacity) yang potensial untuk kembangkan kreativitas.

Sebagaimana yang diungkapkan oleh B. Croce (1960) narasi sejarah merupakan "contemporary thought about the past". Setiap tulisan sejarah merupakan hasil seleksi fakta yang dipilih dan direkonstruksi oleh penulisnya sesuai dengan situasi kontemporer yang dihadapinya (Scaff, 1976). Dalam konteks tersebut upaya pembelajaran sejarah sesuai dengan kebutuhan bangsa Indonesia masa kini dan masa depan mempunyai landasan paradigmatis. Pendidikan sejarah bukan sekedar untuk mengenalkan peserta didik mengenal masa lampau tetapi lebih untuk menyiapkan mereka menghadapi masa depannya. Dalam konteks yang semacam ini perspektif akan masa depan harus disadari oleh para pendidik sejarah. "Tanpa perspektif pada hari depan pandangan kita terhadap 
masa yang telah lampau bersifat selesai dan lengkap dank arena itu ia merupakan pandangan yang palsu" sebagaimana yang diungkapkan oleh filsuf sejarah Karl Jaspers (dalam Soedjatmoko, 1984; 66).

Sebenarnya upaya untuk mengkritisi pembelajaran sejarah dari konteks kepentingan nasional sekaligus pengembangan dimensi kemanusiaan sudah dirintis dan dilakukan oleh anak-anak pergerakan. Upaya merekonstruksi zaman keemasan di masa lampau untuk menjelaskan masa kini yang suram dijadikan inspirasi dalam memperjuangkan masa depan yang gemilang dan penuh harapan. Anak-anak pergerakan telah berusaha menempatkan sejarah sebagai bagian dari pelajaran moral sekaligus media penyadaran atau konsientisasi. Penyadaran akan kondisi masyarakat terjajah dengan budaya bisu perlu diakhiri dengan mendorong kemerdekaan berpikir guna mencapai kemerdekaan bangsa dan negara dari kungkungan penjajah. Di alam kemerdekaan diharapkan bangsa Indonesia dapat berkembang lebih utuh, termasuk dalam mengembangkan narasi dan aksi sejarah.

Untuk memenuhi kebutuhan tersebut beberapa buku sejarah ditulis oleh anakanak pergerakan. Pengaruh tulisan mereka masih cukup kuat setelah Indonesia mencapai kemerdekaan. Latar belakang intelektualitas mereka yang cukup baik, walaupun tidak berlatar belakang ilmu sejarah atau pendidikan sejarah, disertai dengan integritas dan kejujuran mampu menghasilkan wacana sejarah cukup baik, menarik dan inspiratif. Penulisan buku yang mirip esai sastra (narativisme) tersebut cenderung tidak membosankan. Bagi generasi zamannya kisah dalam buku tersebut menjadi suatu kenangan yang tidak mudah terlupakan.

Ironisnya dalam perkembangan politik, kisah dan narasi sejarah makin terbelenggu oleh kekuatan politik yang sempit. Kemerdekaan politik yang dicapai bangsa Indonesia tidak serta merta memberi keleluasaan, keseriusan dan ketulusan dalam menyusun kisah sejarah yang lebih manusiawi. Pelbagai kisah sejarah justru dilihat secara sempit. Pelbagai peristiwa sejarah yang kontroversial cenderung dilihat secara linier dari kepentingan kekuasaan yang berusaha mempertahankan system otoritarian. Penjajah sering dijadikan kambing hitam. Demikian pula mereka yang kalah sering dikriminalkan. Belajar sejarah yang diharapkan dapat membangun kearifan dan optimism dalam membangun masa depan sering tergeser oleh jiwa-jiwa kerdil yang berwawasan sempit. Sejarah yang beragam dipaksa untuk seragam (McGregor, 2008).

Manusia yang secara kodrati bersifat jasmani dan rohani tidak hanya dapat hidup dengan hanya terpenuhinya kebutuhan berupa benda-benda materiil. Dalam dimensi kemanusiannya yang utuh manusia juga membutuhkan sesuatu yang bersifat imateriil berupa keindahan, kebenaran dan keluhuran baik dalam ruang religiusitas maupun dalam ruang kekayaan seni dan ilmu pengetahuan. Aspek materiil dan rohani saling 
melengkapi dalam pemenuhan kebutuhan pribadi manusia yang utuh. Belajar sejarah termasuk upaya pemenuhan kebutuhan imateriil sekaligus merenungkan, mengarahkan dan mengembangkan kebudayaan yang bersifat materiil. Melalui pemenuhan dua aspek kebutuhan tersebut manusia memiliki semangat, gairah, nafsu dan harapan untuk merealisasi serta menggapai cita-cita kehidupan dan kemanusiaan secara dinamis.

Lalu bagaimana pandangan atau perspektif pendidik dalam pembelajaran sejarah? Apakah pendidik sejarah hanya sekedar memposisikan diri sebagai penyampai warta yang tertulis dalam buku teks atau akan berperan sebagai fasilitator, motivator dan inspirator anak didik sebagai agen sejarah? Kehidupan yang dijalani dan akan dijalani oleh peserta didik jelas berbeda dengan zaman sang pendidik. Konsekuensinya pembelajaran sejarah harus disesuaikan dengan kebutuhan anak didik yang menjalani kehidupan sekarang dan masa yang akan datang. Perspektif para pendidik sejarah perlu dikembangkan dalam suatu perspektif yang terbuka, "cogito terbuka", sehingga memungkinkan pelbagai keragaman yang dijumpai dapat dirajut menjadi kekuatan fungsional sekaligus energi positif. Pendidik sejarah memang mengajarkan peristiwa masa lalu, tetapi dirinya tidak boleh terbelenggu masa lalu dan mendorong subyek didiknya untuk dapat "melampaui" masa lampau. Salah satunya adalah melihat pelbagai ragam sejarah yang ada di Nusantara maupun dunia secara kontekstual.

Sadar posisi merupakan langkah awal dan strategis untuk melakukan perubahan. Setiap pembelajaran perlu mengubah kebiasaan untuk membangun karakter yang positif, mengubah "mindset statis" menjadi "mindset berkembang". "Pendidik yang berani mengubah dirinya" merupakan prasyarat dan langkah awal untuk menciptakan pembelajaran secara menarik dan bermakna dalam melihat dan memaknai pluralitas kehidupan sehari-hari tanpa melupakan posisinya sebagai bagian dari penebar integrasi bangsa. Sebagaimana yang pernah ditulis oleh Sartono Kartodirdjo (1999:21), bahwa; "pendidikan sejarah berfungsi untuk memicu idealisme yang memuat inspirasi dan aspirasi generasi muda; bagaimana eksistensi bangsa tidak hanya dapat dipertahankan tetapi juga terus menerus ditingkatkan".

Pendidik sejarah yang memiliki tanggung jawab moral untuk mencerdaskan anak bangsa dan proses integrasi bangsa dapat kembali menggali etos bangsa dari landasan ideology bangsanya. "Suatu bangsa yang sedang membangun, suatu bangsa yang sedang berjuang, tidak bisa lain daripada melangkahkan kakinya pada jalan yang disinari oleh cita-citanya, dengan penuh kesadaran tentang yang sudah yaitu sejarahnya" (Soedjatmoko, 2004: 64). Penggalian sejarah yang dilakukan oleh pendiri bangsa dan kemudian dijadikan dasar Negara dan pandangan hidup terwujud dalam Pancasila. Nilai-nilai utama 
yang terkandung dalam dasar negara sekaligus pandangan hidup Pancasila mencakup beberapa prinsip nilai dasar dan universal yaitu ketuhanan, kemanusiaan, persatuan, demokrasi dan keadilan dapat menjadi landasan berpikir membangun integrasi bangsa.

Berbasis pada nilai-nilai tersebut karakter subyek didik potensial dikembangkansecara positif dan kreatif. Hal ini perlu penulis tekankan, karena realitas sejarah di masa lampau tidak memiliki makna dan arti yang signifikan sebelum ditafsirkan dan dimaknai oleh manusia. Untuk itu pemahaman terhadap perjalanan sejarah bangsa dalam proses membangsa menjadi sesuatu yang perlu dipahami bersama sebagai memori sekaligus sumber inspirasi menggapai cita-cita bangsa.

\section{EKSISTENSI SEJARAH INDONESIA}

Kebinekaan Nusantara sudah diawali secara geologis dalam proses pembentukan kepulauan. Pada masa Pleistosen belum berakhir terbentang dua daratan yang sangat luas. Dataran yang membentang dan menjadi bagian dari benua Asia dikenal sebagai Dataran Sunda (Sundaland). Daratan yang satunya dan menjadi bagian dari benua Australia disebut Dataran Sahul (Sahulland). Pada zaman Glacial Wurm, lapisan es kutub mencair menyebabkan sebagian wilayah dataran Sunda dan Dataran Sahul tenggelam, sehingga membentuk gugus kepulauan Indonesia dan Philipina. Proses tersebut menyebabkan tidak hanya aspek geologis antar wilayah yang berbeda, melainkan juga flora dan fauna yang ada di dalamnya.

Kehidupan manusia prasejarah banyak meninggalkan jejak di wilayah kepulauan Nusantara. Menurut Oppenheimer (2010), Nusantara menjadi tempat pertemuan, persilangan serta penyerbukan budaya yang sangat kompleks. Perjumpaan dan perkenalan pelbagai kelompok manusia menghasilkan beragam kebudayaan yang sangat kaya.

Sebagai daerah lintas perdagangan dan pelayaran dunia memungkinkan pelbagai unsur budaya baru masuk dan berdialektika dengan unsur-unsur budaya yang sudah ada sebelumnya. Pelbagai pengaruh yang masuk tidak serta merta langsung diterima dan diterapkan, melainkan diolah dan disesuaikan dengan unsur-unsur budaya baru. Kondisi tersebut memungkinkan tumbuh kembangnya "local genius", terutama pada masa pengaruh Hindu Budha dan Islam.

Pada masa kolonial pengaruh luar, baik berupa keyakinan (Nasrani, Katholik dan Protestan) hingga budaya dan ekonomi menambah kebhinekaan yang sudah ada sebelumnya diperkaya. Konsekuensi dari hal tersebut keberagaman etnis hingga keagamaan menjadi makin kompleks dengan munculnya budaya Indies., 
Berangkat dari kondisi sejarah, antropologis dan sosiologis itulah yang menginspirasi para pendiri bangsa untuk membangun suatu tatanan kehidupan berbangsa dan bernegara yang mampu menampung dan melindungi pelbagai perbedaan ras, etnis, keyakinan, bahasa dan budaya yang sudah ada sejak munculnya Nusantara. Pada masa kuno pelbagai keragaman tersebut sering menjadi pembeda dan pembatas antar wilayah. Konsekuensinya integrasi territorial yang dijalankan oleh Negara-negara tradisional sering menimbulkan konflik. Belajar dari kondisi tersebut, tokoh-tokoh pergerakan nasional berusaha membangun nasionalisme yang inklusif dengan didahului integrasi politik melalui wacana (Kartodirdjo, 1999: 23). Itu semua dapat dilakukan oleh para pendiri bangsa dapat terjadi dengan memanfaatkan proses kesatuan ekonomi, administrasi politik dan budaya yang telah dilakukan oleh pemerintah kolonial pada sejak abad XIX hingga awal abad XX (Simbolon, 2007). Nasionalisme yang tidak hanya mengakui perbedaan di antara warga Indonesia melainkan juga menerima kesederajatan dan keadilan dari bangsa asing. Sudah barang tentu, masih diperlukan proses terus menerus untuk menjadikan pola pikir kebhinekaan sebagai salah satu unsur landasan berbangsa dan bernegara yang dinamis dengan menelesuri sejarah yang jauh di masa lampau. Untuk mewujudkan nasionalisme yang inklusif dipilihlah bentuk Negara kesatuan.

"Tidak dapat diingkari bahwa kesatuan itu menjadi persyaratan pokok. Pokok kesatuan itu selanjutnya diangkat sebagai ideology perjuangan kemerdekaan: suatu prinsip yang dianggap sebagai orientasi tujuan pergerakan dan lagi pula sebagai counter ideology terhadap kolonialisme yang memakai strategi devide et impera sebagai prinsip untuk memecah belah serta alat untuk mematahkan kekuatan nasionalisme" (Kartodirdjo, 1999: 18)

Melalui "deep history" (Smail, 2008) terbukti bahwa alam Nusantara dan para penghuninya sangat beragam atau bhineka, termasuk perkembangan otak dan pemikirannya (Harari, 2017). Penelusuran jauh ke belakang mampu membuat konsep kebhinekaan yang sebelumnya dikaitkan dengan kitab Sutasoma pada abad XIV justru dapat ditelusur lebih jauh pada abad VII-VIII. Dalam kisah "Gandawyuha" salah satu untai panel yang ada di Borobudur dalam kajian "Borobudur Writers and Cultural Festival 2017", ternyata juga sudah menampilkan adanya toleransi dan kehidupan yang beragam. Kondisi alam antar wilayah yang satu dengan yang lain berbeda. Demikian pula flora dan fauna yang hidup sangat beraneka ragam. Jenis manusia yang menghuni juga sangat beragam. Keberagaman masyarakat Nusantara tidak hanya terbatas pada agama, ras, etnis, budaya, bahasa saja. Sebelum abad XX belum ada kesadaran akan perasaan sebangsa bagi warga Nusantara.

JPSI, Vol. 1, No., 1, 2018 
Proses penemuan dan pengembangan kesadaran akan identitas diri tersebut terbentuk melalui proses dialog yang mengedepankan kesejajaran dan keadilan. Dialog antar anak-anak pergerakan nasional, maupun dialog mereka dengan tantangan zamannya. Perasaan senasib dan seperjuangan inilah yang melelehkan batas-batas etnisitas dan lokalitas yang sebelumnya diakui sebagai suatu bangsa. Para tokoh pergerakan mulai berusaha menemukan kembali kepercayaan diri dan kemerdekaan masyarakat Nusantara. Mereka berusaha "membangunkan jiwanya", "membangun karakternya", baru kemudian disusul membangun badannya (Yoesoef, 2018). Sejak saat itu mulai berkembang nilai-nilai yang menimbulkan kemauan bersama dalam membangun negara republik tercinta dengan segala cita-cita luhurnya, khususnya memposisikan warga Indonesia yang beragam dalam ranah persatuan bangsa.

Dalam perjalanan menentukan eksistensi bangsa dan negara telah terjadi pergulatan yang diselingi persaingan dan kadang benturan dengan kekerasan yang memakan korban jiwa cukup besar. Masing-masing kelompok berusaha untuk memaknai Indonesia dalam referensi struktur kognitif-kultural yang dominan di kelompoknya. Ketegangan dan gesekan yang terjadi seringkali merangsang kekuatan yang ada menjalin koalisi dengan kekuatan di luar Indonesia dalam menjatuhkan saingannya. Hal ini menjadikan bangsa Indonesia sering kehilangan momentum dalam memanfaatkan pergolakan global untuk kepentingan bangsa sendiri. Lemahnya kemampuan berpikir luas dan reflektif menyebabkan sebagian bangsa Indonesia mudah terjebak pada komunikasi yang manipulatif dan terdistorsi secara sistemik.

Padahal secara konstitutif masalah "nation and character building" telah menjadi perhatian para pendiri bangsa. Baik dalam pembukaan maupun batang tubuh UUD 1945 secara eksplisit disebutkan bahwa pemerintah mengusahakan dan menyelenggarakan satu system pendidikan nasional untuk menanamkan dan meningkatkan keimanan dan ketaqwaan kepada Tuhan Yang Maha Esa serta akhlak mulia sebagai wujud dan realisasi mencerdaskan kehidupan bangsa. Sesuai dengan nilai-nilai Pancasila anak didik sebagai ciptaan Tuhan dengan segala fitrahnya dan tugas memimpin kehidupan yang berharkat dan bermartabat serta menjadi manusia yang bermoral, berbudi luhur dan berakhlak mulia. Kondisi ini semakin meneguhkan bahwa secara historis, keberadaan masyarakat Nusantara tidak dapat dipisahkan dengan keanekaragaman dimensi spiritual. Karakter manusia yang toleran serta aseptif menjadi penting.

Di tengah-tengah masyarakat mengalami "dislokasi" dan "disorientasi", salah satu wahana untuk menemukan identitas diri sekaligus memposisikan diri dalam kehidupan adalah pendidikan sejarah yang reflektif, emansipatoris dan transformatif. Maksudnya dalam proses pembelajaran manusia potensial untuk menemukan sesuatu yang dapat 
menjadi referensi dalam menghadapi realitas yang kini dan di sini serta membantu memberikan perspektif ke masa depan. Sudah barang tentu pembelajaran yang dimaksud bukan hanya sekedar menguasai materi pelajaran sejarah yang dianggap khas dari suatu bidang study melainkan suatu yang memungkinkan perubahan dan pengembangan "mindset yang dinamis dan positif". Hidup, termasuk karakter yang kita miliki merupakan suatu proses dialektika yang terus mengalir hingga kini menuju masa depan. Sebuah being dalam proses becoming.

Sejarah kehidupan membuktikan bahwa realitas yang kini ada bukan sekedar produk dari masa lampau. Realitas diri dan lingkungan yang kini kita tempati dan maknai merupakan suatu rangkaian kausalitas yang selalu terkait dengan konteks zaman yang terus berubah. Dari proses sejarah itulah manusia dapat memposisikan diri sesuai dengan semangat dan dinamika zamannya. Keragaman yang di masa kolonial dijadikan sarana memecah belah (devide et impera) dipertahankan dalam bentuk sterotipe. Dalam konteks tersebut dibutuhkan para pendidik yang mampu menggugah cara tafsir baru terhadap kebhinekaan dalam masyarakat secara kontekstual. Pendidik sejarah tidak boleh hanya focus pada penguasaan materi yang dipelajari. Keragaman sejarah Indonesia perlu dibingkai untuk kepentingan masa depan subyek didiknya agar proses pendidikan tidak terjebak pada gaya bank. Subyek didik dibekali untuk dapat berpikir lateral.

Pendidik perlu menyadari posisinya bukan hanya sekedar menjadi penyambung lidah penulis buku teks, pengingat dan penghafal materi buku ajar. Peran yang lebih utama dari pendidik adalah fasilitator, motivator, dan inspirator yang terus berusaha "membuka hati dan pikiran siswa" agar yang bersangkutan memikili kemauan dan dorongan internal untuk belajar, termasuk belajar dari perbedaan orang lain sehingga menjadi lebih dewasa dan bijak. Mendorong siswa untuk menyadari bahwa hidup adalah gerak yang tidak selalu linier, melainkan selalu terkait dengan sesuatu yang berbeda. Dan setiap gerak menimbulkan perubahan. Dalam mengarungi perubahan manusia memerlukan nilai sebagai pegangan hidup agar tidak mengalami disorientasi nilai. Membangun masa depan bangsa adalah membangun cita-cita.

\section{PENDIDIKAN KARAKTER}

Generasi abad XXI yang juga sering disebut generasi Z dan atau milenial telah hidup dalam era digital dengan segala konsekuensinya (Schmidt \& Cohen, 2014). Tatkala nilainilai lama terasa tidak relevan sementara nilai-nilai baru belum terformulasi dan terinternalisasi sehingga terkesan generasi milenial ini cenderung ahistoris. Pada satu sisi banyak kreativitas yang muncul dari generasi ini. Tampilan yang santai dan ketergantungan pada 
seperangkat peralatan digital membentuk struktur bertingkah dan berpikir yang berbeda. Lanskap kehidupan generasi milenial yang berbeda membutuhkan strategi pembelajaran sejarah yang berbeda. Kehidupan generasi milineal yang sarat dengan dunia visual cenderung bersikap ahistoris bahkan kalau pinjam konsep Freire sebagian besar mereka mudah mengalami 'anesthesia sejarah' (Freire, 2001). Tetapi pada satu sisi banyak diantara generasi milenial yang kreatif dan memiliki daya cipta yang menakjubkan. Belajar dan bermain bisa dipadukan oleh generasi yang memiliki multitasking ini dalam menjawab tantangan zamannya.

Dalam konteks yang demikian masih banyak pihak prihatin dengan karakter bangsa dalam menghadapi tantangan dunia yang telah berubah secara mendasar. Pelapukan dan pengkerdilan karakter yang dialami bangsa Indonesia sebagian merupakan distorsi yang berlangsung "sistematis". "Suatu distorsi yang menjauhkan atau bahkan mengisolasi para pelaku dari akal sehat, sehingga makna-makna yang dihasilkan tidak memiliki acuan pada akal sehat" (Habermas, dalam Hardiman, 2015: 221).

Penulis beranggapan bahwa sebenarnya pendidikan karakter merupakan sesuatu yang inheren dalam dirinya. Setiap pendidikan pada hakekatnya merupakan pengenalan, penanaman dan pengembangan karakter melalui internalisasi dan habituasi nilai (Ryan \& Bohlin, 1999; Nucci \& Darcia Narvaez (ed.) 2014). Hanya melalui pendidikan yang bersumber dari pola pikir (mindset) moralitas bangsa dapat dijaga dan dikembangkan sesuai dengan kebutuhan dan tantangan zaman. Penjelasan Hardiman (2015; 195-6) tentang konsep Bildung versi Gadamer dapat membantu tentang pendidikan dan karakter sebagai suatu yang tidak terpisahkan.

"Untuk menjelaskan apa itu Bildung, kita ambil contoh seorang yang dalam masa hidupnya banyak belajar ilmu-ilmu. Dia membaca teks-teks dalam bidang sejarah, kebudayaan, filsafat, teologi, kesusastraan, dst. Kita menyebut orang seperti ini "terpelajar" bukan hanya karena dia mengetahui banyak informasi ataupun fakta, melainkan karena pengetahuannya yang luas itu membentuk kepribadiannya. Orang itu tidak sekedar belajar hal-hal di luar dirinya, melainkan juga belajar tentang dirinya sendiri. Kegiatan belajarnya membentuk kepribadiannya sebagai seorang terpelajar. Mungkin saja dia melupakan beberapa informasi atau fakta yang pernah dipelajarinya, namun ada hal yang tetap tinggal dalam kepribadiannya, yaitu pembentukan dan perubahan dirinya lewat proses belajar itu".

Pembelajaran tidak hanya untuk mencakup "dimensi penghidupan", melainkan juga memberi "pemaknaan terhadap kehidupan". Belajar sejarah adalah perjalanan mudik, suatu homecoming dalam jiwa. Sejarah dapat memberikan perlindungan zaman bagaikan rumah yang dapat memberikan perlindungan terhadap cuaca. Untuk itu sejarah tidak boleh menjadi beban, pasti ada yang perlu dimaafkan agar tidak terhuyung dalam 
proses zaman. Mereka yang sulit berdamai dengan sejarah mirip seseorang yang tidak bisa mengembara (sosial dan intelektual) meninggalkan kampungnya maka akan sulit tumbuh menjadi pribadi yang dewasa.

Manusia memiliki otonomi diri. Kebebasan manusia memberi ruang untuk "ikut mengambil peran" dalam menentukan proses sejarah. Sejarah tidak lagi dianggap sebagai produk absolut kekuatan di luar diri manusia. Kenyataan tersebut membawa konsekuensi akan peran manusia dalam proses sejarah. Posisi manusia dalam sejarah tidak dianggap sebagai pelaku sejarah yang pasif. Manusia sebagai agen sejarah mempunyai fungsi yang aktif dan dinamis dalam mempengaruhi dan menggerakkan sejarah.

Dalam pendidikan yang reflektif, kritis dan emansipatoris manusia menyadari bahwa Tuhan telah memberi kebebasan pada dirinya untuk mengembangkan diri secara maksimal. Eksistensi manusia sebagai "homo sapiens", mahkluk yang berpikir selalu diminta tanggungjawab. Tuhan hanya meminta pertanggungjawaban pada manusia yang berakal. "Orang yang tidak berakal" tidak pernah diminta tanggungjawab. Ironisnya dalam kehidupan sehari-hari, manusia justru malas berpikir. Kalau diajak berpikir hanya mikir-mikir.

Menurut Harari sejarah homo sapiens berada dalam proses kesinambungan gayagaya fisika, reaksi-reaksi kimia dan proses seleksi biologis sehingga tidak mampu membebaskan diri dari batas-batas yang ditentukan oleh biologi. "Namun pada fajar abad ke21, itu tidak lagi berlaku: Homo sapiens sedang melewati batas-batas itu. Kini Sapiens mulai mematahkan hokum-hukum seleksi alam, menggantinya dengan hokum-hukum desain cerdas" (Harari, 2017: 477).

Ironisnya mayoritas manusia hingga kini cenderung mengelak dari kebebasan, sebagaimana pernah diungkapkan oleh Eric Fromm (1995) dengan menyebutnya "escape from freedom". Mereka cenderung menerima proses perubahan sosial yang ada secara pasif. Mayoritas manusia suka berada dalam perasaan rasa aman yang semu, comfort zone. Kedaulatan diri mereka tergadaikan oleh opini yang diyakini sebagai suatu kebenaran. Seolah hanya orang-orang besar yang dapat melakukan perubahan. Keadaan tersebut ikut menguatkan radikalisasi pasar dan agama sehingga membuat sebagian masyarakat Indonesia menjadi ahistoris.

Kondisi tersebut semakin mengental dengan adanya daya pikat kekuatan ekonomi kapitalis yang menciptakan kesadaran palsu. Manusia makin sulit menempatkan diri sebagai pelaku sejarah yang otonom. Media informasi dan iklan dengan mudah menghipnotis manusia untuk bertindak secara reflex. Pemahaman tentang keinginan (want) telah rancu dengan kebutuhan (need). Tanpa sadar banyak manusia meninggalkan kemampuan refleksi. Belajar lebih diarahkan untuk memiliki lebih, bukan pada menjadi lebih. “Pendeknya, disini pendidikan sejarah berfungsi untuk memicu idealism yang memuat 
inspirasi dan asirasi generasi muda: bagaimana eksistensi bangsa tidak hanya dapat dipertahankan tetapi juga terus menerus ditingkatkan" (Kartodirdjo, 1999; 21). Pendidikan gaya bank perlu ditinggalkan (Kreisberg, 1992)..

Belajar dari pengalaman sejarah tersebut pendidikan harus didekati secara dialogis agar memungkinkan pelbagai perspektif tampil dalam segala multiinterpretasinya. Pendidikan nilai tidak dijadikan alasan untuk mempertahankan status quo. Siswa tidak diorientasikan untuk menghafal materi pelajaran. Siswa difasilitasi untuk merekonstruksi pengetahuan yang dipelajari sekaligus mengembangkan persepsi diri secara positif. Pendidikan di level pendidikan dasar dan menengah perlu lebih diutamakan untuk membekali peserta didik dalam mengantisipasi permasalahan kehidupannya. Sedangkan dalam level pendidikan tinggi juga dikembangkan "kapasitas belajar" yang lebih utuh. Dan secara keseluruhan, subyek didik difasilitasi untuk memiliki "passion for learning", yaitu pebelajar sejati. Menurut Daoed Yoesoef (2018: 339) "pendidikan sejatinya adalah membelajarkan kita bagaimana berpikir (how to think), bukan memikirkan apa (what to think)" sehingga dalam belajar sejarah, (maha)siswa tidak dipaksa menghafal fakta melainkan bisa memikirkan bagaimana fakta yang ada dikonstruksi dan dimaknai nilainya.

Menurut Gardner (2007: 20) ada lima jenis pikiran yang penting di masa depan. Kelima pikiran tersebut adalah terdisiplin, menyintesis, mencipta, merespek, dan etis. Secara rinci disebutkan bahwa;

1. Orang yang tidak memiliki satu atau dua disiplin tidak akan bisa berhasil di semua tempat kerja yang menuntutnya dan hanya akan diberi pekerjaan fisik.

2. Orang yang tidak memiliki kesanggupan mensistensis akan kewalahan dengan informasi dan tidak dapat membuat keputusan bijaksana tentang masalah pribadi atau professional.

3. Orang yang tidak memiliki kesanggupan mencipta akan diganti oleh computer dan atau akan mengusir orang-orang yang kreatif.

4. Orang yang tidak memiliki respek tidak akan layak direspek oleh orang lain dan akan meracuni tempat kerja dan orang di sekitarnya.

5. Orang-orang yang tanpa etika akan menghasilkan suatu dunia tanpa para pekerja yang bermoral dan warga yang bertanggung jawab; tidak ada yang mau hidup dalam planet tak berpenghuni seperti itu.

Tentu ini membutuhkan karakter dan sikap hidup yang berbeda dengan masa sebelumnya. Belajar bukan sekedar mengadopsi cara berpikir baru, melainkan juga membuang cara berpikir lama (learn, unlearn and relearn). Membangun karakter yang positif sesuai dengan mindset berkembang membutuhkan perjuangan dan kerja keras. Kita 
perlu melakukan orientasi ulang secara mendasar terhadap cara pembelajaran. Rajin, jujur dan suka kerja keras memang penting. Tetapi kreativitas yang memungkinkan diri kita memiliki kompetensi akademik, social dan spiritual menjadi suatu keniscayaan di era sekarang.

Dengan kata lain mereka diajak belajar secara utuh dan mendalam dengan prinsip bermain dan menghindari sikap main-main. Pembelajaran dalam suasana bermain potensial menimbulkan inspirasi bagi perkembangan intelektual dan emosional siswa dan guru. Mereka dirangsang untuk berani melakukan dekonstruksi wawasan serta kesadaran yang sudah dimiliki berdasarkan pertimbangan yang didukung oleh nalar dan bukti yang akurat.

Tumbuhnya kesadaran diri yang positif sekaligus optimis salah satu indikatornya adalah munculnya kesadaran bahwa semua peristiwa sejarah di dunia sangat dipengaruhi oleh kiprah anak-anak manusia. Ada peristiwa sejarah yang berkembang sesuai dengan apa yang diinginkan (intended results) melainkan juga ada perkembangan sejarah yang berkembang secara mendadak dan di luar perkiraan dan atau maksud manusia (unintended results). Hal ini akan semakin kondusif bila pendekatan yang digunakan sebagai landasan interpretasi tidak terlalu berlebihan dalam menekankan aspek struktural. Pendekatan struktural memang bagus dalam menjelaskan bagaimana sistem yang ada mengatur dan membatasi ruang gerak manusia, namun mempunyai kelemahan seolah manusia sebagai agen tidak berdaya dalam melakukan perubahan.

Demikian pula halnya pendekatan perilaku yang berlebihan justru akan mengaburkan peran sistem dan struktur kehidupan yang relatif dominan. Kesadaran peserta didik sebagai agen tetap perlu memahami adanya situasi batas yang selalu ada dalam aktivitas sosial. Barangkali konsep eksternalisasi dalam kaitannya dengan internalisasi dan objektifikasi yang dikemukakan oleh Peter L. Berger dan Thomas Luckman (1990) dapat dijadikan sebagai salah satu penjelasan. Maksudnya peserta didik tidak hanya diberitahu dan diajari tentang pelbagai peristiwa pergulatan anak-anak manusia dengan tantangan jamannya, melainkan juga dirangsang untuk membangkitkan pengetahuan dan kesadaran untuk cancut taliwondo dalam proses sejarah yang dihadapi oleh bangsanya.

Peserta didik dirangsang untuk berani mempertanyakan kisah sejarah termasuk asumsi yang mendasarinya sebagai referensi untuk mempertanyakan dirinya sendiri. Maksudnya dengan terbiasa bertanya, peserta didik mendapat ruang untuk mempertanyakan kembali kepercayaan-kepercayaan yang bersifat self-limiting. Self-limiting belief adalah apa saja yang dipersepsikan dan diyakini oleh peserta didik bahwa dirinya terbatas dan tidak mampu dalam bidang tertentu sehingga membatasi pengembangan potensi dirinya secara maksimal. Potensi anak didik dapat dikembangkan secara maksimal melalui pembentukan karakter yang positif (Tracy, 2007: 47). 
Sebuah karakter bangsa harus dibangun dengan tetap berpijak pada kemampuan riil yang dimiliki oleh bangsa Indonesia. Salah satunya adalah menggalang dan mengaktualisasikan nilai-nilai luhur sehingga mampu menjadi etos yang mendorong vistuositas (keunggulan) bangsa. Kebanggan nasional yang kini terkoyak oleh pelbagai perilaku yang sarat dengan kejahatan sosial perlu segera diantisipasi secara kritis dan kreatif. Dorongan untuk memberlakukan transparansi dalam pelbagai kebijakan dan kepentingan publik sehingga muncul akuntabilitas menjadi tugas bersama.

Merupakan kewajiban bagi kita bersama membangun pola pkir dan etos kerja yang lebh berkualitas. Untuk itulah "kebhinekaan" yang sudah lama menjadi karakter bangsa layak dikembangkan sebagai salah satu komponen soft skill yang dimiliki bangsa Indonesia dalam percaturan globalisasi. Kebiasaan dalam keberagaman memudahkan tumbuhnya pola pikir terbuka serta dikap inklusif yang potensial melahirkan lahirnya pemikiran dan kreatvitas baru yang unggul sebagaimana pertemuan galur murni yang berbeda yang dapat menghasilkan bibit-bibit unggul.

Kita perlu terus membangun karakter dan moralitas dalam proses pembelajaran sejarah. Menurut Soedjatmoko, "tanpa peningkatan dan penjernihan kesadaran sejarah, kita akan gagal dalam usaha pembangunan' untuk itu menurutnya

"Buanglah cara-cara mengajar yang mengutamakan pengetahuan fakta sejarah. Pengetahuan belaka tentang fakta fakta sejarah bukan membikin seseorang menjadi ahli sejarah. Sebaiknya kita melihat sejarah dan penulisan sejarah Indonesia sebagai usaha yang belum selesai, dan yang menjadi tugas bersama dari pengajar maupun yang diajar" (Soedjatmoko, 1986; 70).

Dalam konteks yang demikian dibutuhkan sarana dan pemahaman nilai sehingga kesedihan dan keprihatinan terhadap nasib bangsa menjadi kepedulian yang dapat memicu etos perjuangan dan kerelaan berkorban. Pengembangan karakter dalam dunia pendidikan harus bermuara pada berkembangnya etos kerja dan moralitas bangsa yang unggul dan luhur.

Salah satu sarana mengembangkan nilai-nilai yang luhur dapat dipetik dari para pendiri bangsa. Sikap hidup yang jujur, suka bekerja keras dan bersahaja kini terkesan sebagai gambaran yang langka ditemukan dalam kehidupan sehari-hari. Pencaharian kebenaran dan keutamaan akademik mampu membangkitkan pengharapan akan adanya perubahan nasib bangsa lebih baik. Mereka cukup sabar, ulet, mengutamakan kualitas, kerjakeras, rendah hati, prihatin dan peduli pada nasib bangsa. Nilai-nilai tersebut telah menjadi gaya hidup para pendiri negara.

Memang mengharap keteladanan dari elite pemerintah dan politik yang ada sekarang terasa sulit. Pejabat politik dan publik pasca jatuhnya Soeharto sebagai presiden 
banyak yang belum mampu menunjukkan kepedulian yang cukup signifikan dalam menumbuhkembangkan etos virtuositas bangsa di masa depan. Di sinilah untungnya belajar secara reflektif, kritis dan emansipatoris. Anak-anak pergerakan nasional yang dipelopori oleh Kartini, Tirtoadisuryo, Wahidin, Sutomo, Suwardi Suryaningrat, Agus Salim, Tan Malaka, Soekarno, Hatta, Sjahrir dll adalah contoh manusia dalam pergulatan sejarah yang tidak terjebak pada keteladanan. Pendidikan sejarah dapat memberikan peluang mempelajari tokoh dan perjuangannya dalam lintas waktu dan ruang.

Melalui "vicarious learning" kita dapat belajar dari lintas jaman dan area. Keteladanan dapat diambil dari kerelaan dan kesahajaan generasi sebelum kita dan atau kehidupan yang dipraktekkan di negara lain. Hal ini dimaksudkan agar pembentukan karakter bangsa tidak bersifat eksklusif, melainkan selalu bersinergi dengan pelbagai pengaruh asing. Kepribadian bangsa yang luwes tanpa kehilangan sikap kritis telah banyak ditunjukkan oleh nenek moyang Indonesia dalam kreasi budaya yang sering disebut local genius. Prinsip nasionalisme yang terdiri dari unity, liberty, equality, personality dan performance masih relevan dengan tantangan yang dihadapi oleh bangsa Indonesia sekarang.

Pendidikan karakter dalam pembelajaran menjadi suatu yang bersifat inheren. Tidak ada kata terlambat untuk memperbaharui dan memantabkan karakter bangsa selama masih ada kemauan. Biasanya kemauan dan keberanian yang tulus justru tumbuh dari tunas-tunas bangsa yang belum terlalu terseret dan terkontaminasi kejahatan social semacam korupsi, kolusi dan neoptisme (KKN). Di tangan mereka nasib bangsa akan ditentukan. Apakah kelak Indonesia tetap ada sebagai bangsa yang berkarakter dengan sikap arifnya dalam mengelola kebhinekaan atau justru bangsa yang tidak berkarakter.

Tentu ini membutuhkan karakter dan sikap hidup yang berbeda dengan masa sebelumnya. Tanpa kisa sadari globalisasi industri telah berubah menjadi globalisasi individual. Persepsi diri perlu diubah agar tidak hanya puas menjadi orang yang sedang-sedang saja (mediocre). Kita perlu melakukan orientasi ulang secara mendasar terhadap cara kita mendidik siswa kita selama ini. Rajin, jujur dan suka kerja keras memang penting. Tetapi kreativitas yang memungkinkan diri kita memiliki kompetensi akademik, social dan spiritual menjadi suatu keniscayaan di era sekarang. Dalam revolusi digital yang juga sering disebut revolusi 4.0 membutuhkan suatu karakter dan prinsip kehidupan yang dinamis dari anak-anak bangsa agar tidak gagap menyikapi perkembangan kecerdasan artisial. Seseorangyang berhasil diera dirupsi adalah mereka yang berhasil melakukan dirupsi diri, memiliki agilitas, bermental pengemudi, berani melakukan ekskusi hingga kemampuan mencipta. (Kasali, 2017)

Bangsa Indonesia ke depan dapat menjadi bangsa yang maju dan sejahtera tatkala warga negaranya cerdas dan berkarakter. Kecerdasan memungkinkan kreativitas, daya 
cipta dan penemuan berkembang secara pesat. Mereka dapat menyikapi pelbagai penemuan yang bersifat disrupsi di era revolusi 4.0 secara cerdas dan bijak. Berkarakter dicirikan oleh rasa ingin tahu, kuirositas, yang diiringi dengan disiplin, teliti, tidak mudah menyerah sehingga memungkinkan terlibat dalam inventivitas sehingga dapat menjadi kelompok kecil yang kreatif dalam mempelajari peradaban masa lampau serta menerawang dan memperjuangkan peradaban kedepan yang lebih baik.

\section{SIMPULAN}

Pendidikan karakter dalam pembelajaran sejarah merupakan suatu keniscayaan. Berbagai karakter yang baik yang diperlukan oleh peserta didik untuk menghadapi tantangan dalam revolusi industri 4.0 dapat digali dan diinternalisasikan melalui pembelajaran sejarah. Namun untuk memulai semua itu perlu diawali dengan perubahan mindset atau cara berpikir pendidik dari mindset statis menuju mindset berkembang. Berbagai karakter dapat digali dari tokoh maupun peristiwa yang terjadi baik di Indonesia maupun di dunia. Selain itu, pendidik perlu melakukan reinterpretasi dan reorientasi terhadap cara mendidik (maha)siswa karena dalam dunia yang terus berubah peserta didik suatu karakter dan prinsip kehidupan yang dinamis dari anak-anak bangsa agar tidak gagap menyikapi perkembangan. Karakter perlu dibarengi dengan kecerdasan yang melahirkan kreativitas dibarengi dengan agilitas dan kemampuan beradaptasi yang tinggi dalam menghadapi disrupsi digital.

\section{RUJUKAN}

Berger, P. \& Luckmann. 1990. Tafsir Sosial atas Kenyataan: Risalah tentang Sosiologi Pengetahuan. Jakarta: LP3ES.

Bigge. M.L. 1993. Learning Theories for Theachers. New York: Harper \& Row.

Croce, B. 1960. History: Its Theory and Practice. New York: Harcourt Brace and Company.

Dewantara. K.H. 2013. Pemikiran, Konsepsi, Keteladanan, Sikap Merdeka I (Pendidikan). Yogyakarta: Majelis Luhur Persatuan Tamansiswa.

Freire. P. 1984. Pendidikan sebagai Praktek Pembebasan. Jakarta: Gramedia.

Freire, P.2001. Pedagogi Hati. Yogyakarta: Kanisius.

Fromm, E. 1995. Masyarakat yang Sehat. Jakarta: Yayasan Obor Indonesia.

Gardner, H. 2007. Five Minds for The Future; Lima Jenis pikiran yang penting di masa depan. Terj. Tome Beka. Jakarta: Gramedia Pustaka Utama. 
Harari, Y.N. 2017. Sapiens, Riwayat Singkat Umat Manusia. Jakarta: Kepustakaan Populer Gramedia.

Hardiman, F.B. 2015. Seni Memahami; Hermeneuitik dari Schleiermacher sampai Derrida. Yogyakarta: Kanisius.

Johnson, E.B. 2007. Contextual Teaching and Learning: Menjadikan Kegiatan Belajar Mengajar Mengasyikkaan dan Bermakna. Bandung: MLC

Kartodirdjo, S. 1993. Pembangunan Bangsa, tentang Nasionalisme, Kesadaran dan Kebudayaan Nasional.Yogyakarta: Aditya Media.

Kartodirdjo, S., 1999, Multidimensi Pembangunan Bangsa; Etos Nasionalisme dan Negara Kesatuan. Yogyakarta: Kanisius.

Kasali, R. 2017. Disruption. Jakarta: Gramedia Pustaka Utama.

Kleden, I. 1987. Sikap Ilmiah dan Kritik Kebudayaan. Jakarta: LP3ES.

Koentjaraningrat. 1987. Sejarah Teori Antropologi I. Jakarta: UI Press.

Kreisberg. S. 1992. Transforming Power; Domination, Empowerment and Education. New York: State University of New York Press.

Lubis, M. 1981. Manusia Indonesia (Suatu Pertanggungjawaban). Jakarta: Yayasan Idayu.

McGregor. K.E. 2008. Ketika Sejarah Berseragam; membongkar ideology militer dalam menyusun sejarah Indonesia. Yogyakarta: Syarekat.

Nucci, L.P. \& Darcia N. (ed.) 2014. Handbook Pendidikan Moral dan Karakter. Bandung: Nusamedia.

Oppenheimer, S. 2010. Eden in the East: Surga di Timur.Jakarta: Ufuk Press.

Palmer, P.J. 2009. Keberanian Mengajar; Menjelajahi Ruang Nurani Kehidupan Guru. Jakarta: Indeks.

Poespowardojo, S. 1989. Strategi Kebudayaan, Suatu Pendekatan Filosofis. Jakarta: Gramedia.

Ryan, K. \& Bohlin, K. 1999. Building Character in School. San Fransisco: John Wiley \&sons, Inc.

Scaff. A. 1976. History \& Truth. Oxford: Pergamon Press.

Schmidt, E. \& Cohen, J. 2014. The New Digital Age, Reshaping The Future of People, Nations and Business. London: John Murray.

Simbolon, 2007. Menjadi Indonesia. Jakarta: Kompas

Smail, D. L. 2008. On Deep History and The Brain. Bekeley: University of California.

Soedjatmoko. 1984. Etika Pembebasan. Jakarta: LP3ES. Hal. 32-33.

Soedjatmoko. 1986. Dimensi Manusia dalam Pembangunan. Jakarta: LP3ES

JPSI, Vol. 1, No., 1, 2018 
Soe

djatmoko. 2004. Kebudayaan Sosialis. Jakarta: Melibas.

Soekarno. 2017. Filsafat Pancasila menurut Bung Karno. Peny. Floribetta Aning. Yogyakarta: Media Pressindo.

Tracy, B. 2007. Change Your Thinking Change Your Life; Bebaskan potensi dahsyat anda untuk kesuksesan yang tak terbatas. Bandung: Kaifa.

Yoesoef, D. 2018. Bangunlah Jiwanya, Bangunlah Badannya. Jakarta: Penerbit Buku Kompas.

Wibowo, A.S. Epilog, Merawat Jiwa dalam Demokrasi Fenomenologi dan Politik Jan Patocka, dalam Ito Prajna-Nugroho, 2013. Fenomenologi Politik, Membongkar Politik Menyelami Manusia, Jakarta: Sanggar Pembasisan Pancasila. 